\section{Nitrate and Ammonium Leaching Losses from $\mathbf{N}$ Fertilizers Applied to 'Penncross' Creeping Bentgrass}

\author{
Charles F. Mancino ${ }^{1}$ and Joseph Troll \\ Department of Plant and Soil Sciences, University of Massachusetts, \\ Amherst, MA 01002
}

\section{Additional index words. Agrostis palustris, fertilizer fate, turfgrass}

\begin{abstract}
Combining frequent $\mathrm{N}$ applications and irrigations for turfgrasses grown in sandy soils is a common occurrence on golf course putting greens. A greenhouse study was conducted to determine leaching losses of nitrate and ammonium nitrogen from 'Penncross' creeping bentgrass (Agrostis palustris L.) growing on an 80 sand :20 peat soil mixture following frequent, moderately heavy irrigations and light or moderate $\mathbf{N}$ fertilizer applications. Nitrogen sources included calcium nitrate, ammonium nitrate, ammonium sulfate, urea, urea formaldehyde and isobutylediene diurea. Application levels were $9.76 \mathrm{~kg}$ N/ha per 7 days and $19.52 \mathrm{~kg}$ N/ha per 14 days for 10 weeks. Irrigation equivalent to $38 \mathrm{~mm} \cdot$ week $^{-1}$ was applied in three equal applications. Overall, $46 \%$ of the applied water leached. Total leaching losses were $<0.5 \%$ of the applied $N$. Nitrate represented the major portion of the leached $N$, with ammonium losses being negligible. There were no differences between sources when applied at these levels. In a second study, a single $48.8 \mathrm{~kg} \mathrm{~N} / \mathrm{ha}$ application resulted in higher leaching losses of $\mathrm{N}$, but only calcium nitrate and ammonium nitrate had total losses $>2 \%(2.80 \%$ and 4.13\%, respectively, over an n-day period). Nitrate concentrations were found to exceed $45 \mathrm{mg}$ liter $^{-1}$ for ammonium nitrate.
\end{abstract}

Sand, sand : peat, and sand : peat : soil mixtures make excellent root-zone mediums for golf course putting greens because they are well-aerated, increase rooting depth, and, to a degree, resist compaction. However, because of a lack of an adequate soil moisture reserve, low nutrient retention, and innate infertility, there is a need to frequently irrigate and fertilize turf growing on these artificial. soil mixtures (Hall, 1980; Holmes, 1980). As a result, the potential for leaching losses of nutrients, particularly $\mathrm{N}$, is high. High nitrate $\left(\mathrm{NO}_{3}^{-}\right)$levels in surface and groundwater make it unfit for human consumption and serve as a nutrient for undesirable microorganisms and aquatic higher plants.

Nutrient leaching losses can be low from fertilizers applied to turfgrass or pasture grasses on native soils (Jones et al., 1974; Starr and DeRoo, 1981; Petrovic and Hummel, 1985). This appears to be true even when quick-release (highly water-soluble) $\mathrm{N}$ sources are applied at excessive rates (Chichester, 1977; Dowdell and Webster, 1980). The low leaching losses from these grass swards can be partially attributed to the efficiency of the grass root system in exploiting nutrients (Allison, 1958).

General findings indicate that $\mathrm{N}$ leaching losses, occurring primarily as $\mathrm{NO}_{3}$, are higher from quick-release-N sources, and are en-

Received for publication 29 Aug. 1988. The cost of publishing this paper was defrayed in part by the payment of page charges. Under postal regulations, this paper therefore must be hereby marked advertisement solely to indicate this fact.

'Current address: Dept. of Plant Sciences, Univ. of Arizona, Tucson, AZ 85721. hanced by well-drained sandy soils (Volk and Bell, 1945; Bates and Tisdale, 1957; Reike and Ellis, 1974; Smika et al., 1977; Mitchell et al., 1978; Petrovic et al., 1986). Brown et al. $(1977 ; 1982)$ found that up to $23 \%$ of the $\mathrm{N}$ applied as ammonium nitrate could be leached from a Cynodon dactylon $\times$ transvaalensis sand : peat putting green. However, their application rate of $163 \mathrm{~kg} \mathrm{~N} / \mathrm{ha}$ was excessive, although leaching losses could be minimized by reducing the irrigation rate to meet evapotranspirational needs of the turf. Reike and Ellis (1974) found that turf plots on sandy soil fertilized with $390 \mathrm{~kg} \mathrm{~N} / \mathrm{ha}$ from ammonium nitrate resulted in $\mathrm{NO}_{3}-\mathrm{N}$ concentrations of up to $111.4 \mathrm{mg} \cdot \mathrm{liter}^{-1}$ in the 0-to $15-\mathrm{cm}$ depth of soil and $44 \mathrm{mg} \cdot \mathrm{liter}^{-1}$ at 15 to $30 \mathrm{~cm}$. Even when the $390 \mathrm{~kg} \mathrm{~N} / \mathrm{ha}$ application was made in three equal applications, the movement of nitrates occurred to a depth of 45 to $60 \mathrm{~cm}$. Annual leaching losses for this study were related to rates of application, precipitation, and irrigation. A normal golf course application would not exceed $49 \mathrm{~kg} \mathrm{~N} / \mathrm{ha}$ of a quick-release $\mathrm{N}$ source.

The objectives of our study were to quantify maximum leaching losses of $\mathrm{NO}_{3}$ and ammonium $\left(\mathrm{NH}_{4}^{+}\right) \mathrm{N}$ from containerized putting green turf receiving weekly and biweekly light to moderate $\mathrm{N}$ applications coupled with thrice weekly heavy irrigations. Nitrogen leaching losses were then measured after a single, heavy $\mathrm{N}$ application (48.8 kg N/ha).

Multiple applications (Expt. 1). Fifty-six 15.4-liter plastic pots ( $30.5 \mathrm{~cm}$ top diameter) were each filled with $16.8 \mathrm{~kg}$ of an 80 sand :20 sphagnum peat (v/v) mixture and packed to a bulk density of $1.1 \mathrm{~g} \cdot \mathrm{cm}^{-3}$. Most of the sand $(81 \%)$ was in the $0.1-$ to $1.0-\mathrm{mm}$ size range. Dolomitic limestone was added toadjust the $\mathrm{pH}$ of the soil to 6.2. Each pot was placed in the greenhouse and seeded with 0.4 $\mathrm{g}$ of 'Penncross' creeping bentgrass. After germination, the turf was maintained as stated below for a period of 10 months before experimentation. A $10 \mathrm{~N}-10 \mathrm{P}-10 \mathrm{~K}$ fertilizer was applied at $5.5 \mathrm{~kg} \mathrm{~N} / \mathrm{ha}$ whenever the turf began to exhibit a $\mathrm{N}$ deficiency. The turf was watered three times per week for a total of $38 \mathrm{~mm}$ (2.8 liters) of water/pot per week. The grass was mowed three times per week at $1.3 \mathrm{~cm}$ and clippings were removed with a hand-held vacuum cleaner. The greenhouse was held at $21 \mathrm{C}$ days and. $18 \mathrm{C}$ nights.

Mowing height was reduced to $6 \mathrm{~mm} 3$ weeks before experimentation. Fluorescent light banks delivered $12 \mathrm{hr}$ of light/day at an intensity of $165 \mu \mathrm{mol} \cdot \mathrm{s}^{-1} \cdot \mathrm{m}^{-2}$.

For 10 weeks, 24 pots received $9.76 \mathrm{~kg}$ $\mathrm{N} /$ ha per 7 days from one of six sources of $\mathrm{N}$, while another 24 pots received $19.52 \mathrm{~kg}$ $\mathrm{N} /$ ha per 14 days. Eight control pots did not receive $\mathrm{N}$

Water-soluble $\mathrm{N}$ fertilizers included urea, $\mathrm{NH}_{4} \mathrm{NO}_{3}$, ammonium sulfate $\left(\mathrm{NH}_{4}\right)_{2} \mathrm{SO}_{4}$, and calcium nitrate $\mathrm{Ca}\left(\mathrm{NO}_{3}\right)_{2}$, each of which was applied in $200 \mathrm{ml}$ of water as a drench. Waterinsoluble $\mathrm{N}$ fertilizers [urea formaldehyde (UF) and isobutylidiene diurea (IBDU)] were applied in granular form. Immediately after a fertilizer application, fertilized and unfertilized pots were placed in individual trays and the first of the three weekly waterings was administered. Leachate was collected, the volume recorded, and a 40-ml subsample taken. Three subsamples were collected and combined on a weekly basis for $\mathrm{NO}_{3}$ and $\mathrm{NH}_{4}^{+}$determinations. Total milligrams of $\mathrm{N}$ in leachate was calculated from the weekly $\mathrm{N}$ determinations and total leachate volume over the 10 -week period. Percentage of $\mathrm{N}$ applied that leached was calculated as the

Table 1. Total $\mathrm{N}$ teaching losses from various $\mathrm{N}$ fertilizers applied at two levels to 'Penncross' creeping bentgrass for 10 weeks.

\begin{tabular}{|c|c|c|c|}
\hline Source & $\begin{array}{l}\text { Application } \\
\text { level }^{2, y}\end{array}$ & $\begin{array}{c}\text { Total N } \\
\text { lost } \\
(\mathrm{mg})^{x, w}\end{array}$ & $\begin{array}{c}\mathrm{N} \text { applied } \\
\text { lost } \\
(\%)\end{array}$ \\
\hline \multirow[t]{2}{*}{ Urea } & 1 & 0.49 & 0.00 \\
\hline & 2 & 0.99 & 0.02 \\
\hline \multirow{2}{*}{$\mathrm{Ca}\left(\mathrm{NO}_{3}\right)_{2}$} & 1 & 2.89 & 0.20 \\
\hline & 2 & 3.66 & 0.27 \\
\hline \multirow[t]{2}{*}{$\mathrm{NH}_{4} \mathrm{NO}_{3}$} & 1 & 2.04 & 0.12 \\
\hline & 2 & 4.12 & 0.32 \\
\hline \multirow[t]{2}{*}{$(\mathrm{NH}$} & ${ }_{4} 1$ & 0.71 & 0.00 \\
\hline & 2 & 0.57 & 0.00 \\
\hline \multirow[t]{2}{*}{ UF } & 1 & 0.59 & 0.00 \\
\hline & 2 & 0.56 & 0.00 \\
\hline \multirow[t]{2}{*}{ IBDU } & 1 & 0.92 & 0.02 \\
\hline & 2 & 0.89 & 0.01 \\
\hline Control & NA & 0.76 & NA \\
\hline
\end{tabular}

${ }^{2}$ Level $1=9.76 \mathrm{~kg} \mathrm{~N} / \mathrm{ha}$ per 7 days; level $2=$ $19.52 \mathrm{~kg} \mathrm{~N} / \mathrm{ha}$ per 14 days.

'Total $\mathrm{N}$ applied equivalent to $1063 \mathrm{mg} \mathrm{N}$ on a container basis.

${ }^{\mathrm{x}} \mathrm{LSD}_{(0.05)}$ for level $1=0.88 \mathrm{mg} \mathrm{N}$; level $2=$ $0.50 \mathrm{mg} \mathrm{N}$.

"Data are the means of four replications, except the control, which had eight.

$\mathrm{NA}=$ not applicable. 
Table 2. Total turf clipping weights after 10 weeks of application of various $\mathrm{N}$ fertilizers at two levels to 'Penncross' creeping bentgrass.

\begin{tabular}{lcc}
\hline \hline & \multicolumn{2}{c}{ Application level } \\
\cline { 2 - 3 } Source & $\begin{array}{c}9.76 \mathrm{~kg} \mathrm{~N} / \mathrm{ha} \\
\text { per 7 days }\end{array}$ & $\begin{array}{c}19.52 \mathrm{~kg} \mathrm{~N} / \mathrm{ha} \\
\text { per } 14 \text { days }\end{array}$ \\
\hline & \multicolumn{2}{c}{ Dry } \\
Urea & $1.2 \mathrm{abc}$ & $1.3 \mathrm{a}$ \\
$\mathrm{Ca}\left(\mathrm{NO}_{3}\right)_{2}$ & $1.4 \mathrm{ab}$ & $1.3 \mathrm{ab}$ \\
$\mathrm{NH}_{4} \mathrm{NO}_{3}$ & $1.6 \mathrm{ab}$ & $1.4 \mathrm{a}$ \\
$\left(\mathrm{NH}_{4}\right)_{2} \mathrm{SO}_{4}$ & $1.8 \mathrm{a}$ & $1.5 \mathrm{a}$ \\
$\mathrm{UF}$ & $0.7 \mathrm{c}$ & $0.8 \mathrm{c}$ \\
IBDU & $1.0 \mathrm{bc}$ & $1.0 \mathrm{~b}$ \\
Control & $0.9 \mathrm{c}$ & $0.8 \mathrm{c}$ \\
\hline
\end{tabular}

${ }^{2}$ Means separation in columns, Duncan's new multiple range test $(\mathrm{P}=0.05)$.

${ }^{y}$ Data are the means of four replications, except the control, which had eight.

Table 3. Total $\mathrm{N}$ leaching losses over 11 days from various $\mathrm{N}$ fertilizers applied to 'Penncross' creeping bentgrass in a single application of 48.8 $\mathrm{kg} \mathrm{N} / \mathrm{ha}^{2 .}$

\begin{tabular}{lcc}
\hline \hline Source & $\begin{array}{c}\text { Total N } \\
\text { lost } \\
(\mathrm{mg})\end{array}$ & $\begin{array}{c}\text { N applied } \\
\text { lost } \\
(\%)\end{array}$ \\
\hline $\mathrm{Urea}$ & 0.31 & 0.00 \\
$\mathrm{Ca}\left(\mathrm{NO}_{3}\right)_{2}$ & 10.42 & 2.80 \\
$\mathrm{NH}_{4} \mathrm{NO}_{3}$ & 15.21 & 4.13 \\
$(\mathrm{NH} 4) \mathrm{SO}_{4}$ & 0.67 & 0.09 \\
$\mathrm{UF}$ & 0.37 & 0.01 \\
$\mathrm{IBDU}$ & 1.25 & 0.26 \\
Control & 0.33 & NA \\
LSD $(0.05)$ & 4.07 & --- \\
\hline
\end{tabular}

${ }^{2}$ Nitrogen application equivalent to $360 \mathrm{mg} \mathrm{N}$ on a container basis.

'Data are the means of eight replications, except the control, which had 16.

$\mathrm{NA}=$ not applicable.

difference between total $\mathrm{N}$, leached from treated pots and total $\mathrm{N}$ in leachate from the controls. When $\mathrm{N}$ from the control pots exceeded that of treated pots, the percentage of applied $\mathrm{N}$ that leached was reported as zero.

Overall, $46 \%$ of the water applied leached. The subsamples were stored at $4 \mathrm{C}$ until analysis. Nitrate-N concentrations in leachate were determined using an Orion $\mathrm{NO}_{3}$ Specific Electrode Model 93-07 (Orion Research, "Inc., Cambridge, Mass.) and standard procedures (Barker, 1974). Ammonium determinations were made using a modified indophenol reaction (Chancy and Marbach, 1962).

Turf clippings were collected after each mowing and combined on a weekly basis. They were dried at $70 \mathrm{C}$ for $48 \mathrm{hr}$ and dry weights recorded.

A completely randomized design was used during this experiment with four replications per treatment, except for the control, which had eight replications. All pots were rotated randomly under the light banks three times per week to minimize localized lighting effects.

Single application (Expt. 2). This study was conducted with the same turf used in Expt. 1. Lighting, irrigation, mowing, and turf clipping collection were identical to the previous experiment. Fertilizer types were the same; however, a single $48.8 \mathrm{~kg} \mathrm{~N} / \mathrm{ha}$ application of fertilizer was applied at the beginning of this 2-week experiment.

A completely randomized design was used during this experiment and there were eight replications per treatment except for the control, which had 16 replications. As in Expt. 1 , pots were rotated under the light banks to minimize localized lighting effects.

Multiple applications. None of the fertilizers applied at either the $9.76 \mathrm{~kg} \mathrm{~N} / \mathrm{ha}$ per 7 days or $19.52 \mathrm{~kg} \mathrm{~N} / \mathrm{ha}$ per 14 days level resulted in large $\mathrm{N}$ leaching losses (Table 1). Losses from all $\mathrm{N}$ sources were $<0.5 \%$ of the applied N. Calcium nitrate and $\mathrm{NH}_{4} \mathrm{NO}_{3}$ treatments resulted in the highest total amount of $\mathrm{N}$ leached (Table 1). The highest percentage of $\mathrm{N}$ lost from a fertilizer was $0.32 \%$ from $\mathrm{NH}_{4} \mathrm{NO}_{3}$-treated turf. Urea, $\left(\mathrm{NH}_{4}\right)_{2} \mathrm{SO}_{4}$, and UF at $9.76 \mathrm{~kg} \mathrm{~N} / \mathrm{ha}$ per 7 days, and UF at $19.52 \mathrm{~kg} \mathrm{~N} / \mathrm{ha}$ per 14 days, resulted in $\mathrm{N}$ losses that were less than that of the control. Nitrate concentrations were negligible (Mancino, 1983). It appears that increased turfgrass vigor enabled the root system of the turf to intercept more $\mathrm{N}$ from a fertilizer or non-fertilizer source (mineralization) than the $\mathrm{N}$-deficient control plants. This result supports the findings of Allen et al. (1978). Although UF and IBDU did not result in higher clipping yields when compared to the controls (Table 2), we observed that these treated pots had better color and quality. Isobutylediene diurea applied to a 'Penncross' bentgrass sand: peat putting green at levels applied in this study had significantly higher quality ratings than control and UF-treated plots

Table 4. $\mathrm{NO}_{3}$ leachate concentrations following a single $48.8 \mathrm{~kg} \mathrm{~N} / \mathrm{ha}$ application of various $\mathrm{N}$ sources to 'Penncross' creeping bentgrass.

\begin{tabular}{llllllll}
\hline $\begin{array}{l}\text { Days } \\
\text { after } \\
\text { application }\end{array}$ & Urea & $\mathrm{Ca}\left(\mathrm{NO}_{3}\right)_{2}$ & $\mathrm{NH}_{4} \mathrm{NO}_{3}$ & $\left(\mathrm{~N} \mathrm{H}_{4}\right)_{2} \mathrm{~S} \mathrm{O}_{4} \mathrm{U} \mathrm{F}$ & IBDU & Control \\
\hline \multicolumn{7}{c}{$\mathrm{NO}_{3}\left(\right.$ mg.liter $\left.^{-1}\right)$} \\
0 & $0.27^{2}$ & 40.46 & 68.81 & 0.30 & 0.99 & 6.00 & 0.83 \\
2 & 0.14 & 37.10 & 46.75 & 0.57 & 0.69 & 3.26 & 0.53 \\
4 & 0.56 & 25.61 & 30.94 & 0.39 & 0.50 & 2.25 & 0.61 \\
7 & 0.23 & 7.87 & 9.76 & 0.29 & 0.33 & 0.37 & 0.34 \\
9 & 0.17 & 2.84 & 2.34 & 0.28 & 0.50 & 0.20 & 0.25 \\
11 & 0.29 & 0.58 & 1.47 & 0.31 & 0.25 & 0.24 & 0.15 \\
LSD $(0.05)=$ & $2.59 \mathrm{mg} \cdot$ liter $^{-1}$ & & & & & \\
\hline
\end{tabular}

${ }^{2}$ Data arc the means of eight replications, except the control, which had 16.
(Mancino. 1983).

Ammonium nitrate and $\mathrm{Ca}\left(\mathrm{NO}_{3}\right)_{2}$ treatments resulted in the highest $\mathrm{NO}_{3}$ leachate concentrations, but these never exceeded 1.5 $\mathrm{mg} \cdot$ liter $^{-1}$. Ammonium leachate levels were always negligible. The concentrations of $\mathrm{NO}_{3}$ and $\mathrm{NH}_{4}^{+}$found in this study were similar to those obtained from putting green field plots receiving identical fertilizer and irrigation treatments (Mancino, 1983).

Nitrogen leaching from $\mathrm{Ca}\left(\mathrm{NO}_{3}\right)_{2}$, $\mathrm{NH}_{4} \mathrm{NO}_{3},\left(\mathrm{NH}_{4}\right)_{2} \mathrm{SO}_{4}$, and urea, which are highly water-soluble $\mathrm{N}$ fertilizers, probably was absent because of the low amounts applied at any one time. Ureaformaldehyde and IBDU are not highly water-soluble and would, therefore, be less vulnerable to $\mathrm{N}$ leaching losses, even at higher application rates.

Turf growth was affected by fertilizer type, but not the fertilization schedule used (Table 2). Quick-release $N$ fertilizers commonly surpassed the slow-release $\mathrm{N}$ types in turf clipping yields. Ureaformaldehyde, IBDU, and the control treatments resulted in turf of unacceptable quality. Higher rates of UF or IBDU fertilizers would have to be applied to obtain turf growth and quality comparable to that of the fast-release $\mathrm{N}$ sources.

Single application. Quick-release N sources, when applied in excess, have been shown to contribute more to $\mathrm{N}$ leaching losses than slow-release types (Benson and Barnette, 1938; Brown et al., 1977; 1982). The results of our greenhouse study agree with these findings. When $\mathrm{Ca}\left(\mathrm{NO}_{3}\right)_{2}$ and $\mathrm{NH}_{4} \mathrm{NO}_{3}$ fertilizers were applied in a single $48.8 \mathrm{~kg} \mathrm{~N} /$ ha application, the percentage of $\mathrm{N}$ lost by leaching was $2.80 \%$ and $4.13 \%$, respectively (Table 3). All other treatments resulted in negligible $\mathrm{N}$ leaching losses.

Turf treated with $\mathrm{Ca}\left(\mathrm{NO}_{3}\right)$ and $\mathrm{NH}_{4} \mathrm{NO}_{3}$ resulted in the highest $\mathrm{NO}_{3}$ leachate levels following all irrigations (Table 4). Maximum $\mathrm{NO}_{3}$ concentrations were $\approx 41$ $\mathrm{mg} \cdot 1$ iter $^{-1}$ for $\mathrm{Ca}\left(\mathrm{NO}_{3}\right)_{2}$ and nearly 70 mg.liter ${ }^{-1}$ for $\mathrm{NH}_{4} \mathrm{NO}_{3}$. These concentrations substantiate the concern that $\mathrm{NO}_{3}$ pollution could occur from heavy applications of soluble $\mathrm{N}$ sources and heavy irrigation on sandy mediums. All other treatments, except IBDU, resulted in $\mathrm{NO}_{3}$ leachate concentrations $<1 \mathrm{mg} \cdot$ liter $^{-1}$. We observed in a related field study that turfgrass quality was higher for IBDU-treated plots than for plots receiving UF (Mancino, 1983). Higher IBDU applications appear to result in initially elevated $\mathrm{NO}_{3}$ levels in the soil solution, which give better turf quality and growth than UF, but also may cause greater leaching losses.

Ammonium-N was negligible $(<0.5 \mathrm{mg}$. liter $\left.^{-1}\right)$ in all leachate collected. Ammonium leachate concentrations, however, were higher in leachate from $\left(\mathrm{NH}_{4}\right)_{2} \mathrm{SO}_{4}$-treated turf than from the other plots, suggesting that $\mathrm{NH}_{4}^{+}$ may leach if applied in excess to sandier soils.

The results from these studies indicate that $\mathrm{N}$ leaching losses from water-soluble or -insoluble fertilizers applied to turf can be very low, even when irrigated at a moderately heavy rate. This result applies to sandy soils of putting greens, provided water-soluble fertilizers are not applied in excess. 


\section{Literature Cited}

Allen, S. E., G.L. Tennan, and H.G. Kennedy. 1978. Nutrient uptake by grass and leaching losses from soluble and sulfur-coated urea, and KCl. Agron. J. 70:264-268.

Allison, F.E. 1958. Soil fertility studies in lysimeters containing Lakeland sand. USDA Tech. Bul. 1199:1-62.

Barker, A.V. 1974. Nitrate determinations in soil, water, and plants. Mass. Agr. Expt. Sta. Brd. 611.

Bates, T.E. and S.L. Tisdale. 1957. The movement of nitrate-nitrogen through columns of coarse-textured soil materials. Soil Sci. Soc. Proc. 21:525-528.

Benson, N. and R.M. Barnette. 1938. Leaching studies with various sources of nitrogen. J. Amer. Soc. Agron. 31:44-54.

Brown, K.W., R.L. Duble, and J.C. Thomas. 1977. Influence of management and season on fate of $\mathrm{N}$ applied to golf greens. Agron. J. 69:667-671.

Brown, K. W., J.C. Thomas, and R.L. Duble. 1982. Nitrogen source effect on nitrate and ammonium leaching and runoff losses from greens. Agron. J. 74:947-950.

Chancy, A.L. and E.P. Marbach. 1962. Modified reagents for determination of urea, and ammonia. Clin. Chem. 8(2):130-132.

Chichester, F.W. 1977. Effects of increased fertilizer rates on $\mathrm{N}$ content of runoff and percolate from monolith lysimeters. J. Environ. Qual. 6:211-217.

Dowdell, R.J. and C.P. Webster. 1980. A lysimeter study using nitrogen-15 on the uptake of fertilizer nitrogen by perennial ryegrass swards and losses by leaching. J. Soil Sci. 31:65-75.

Hall, J.R. 1980. Sand top-dressing-look before you leap. Proc. Fifteenth Annu. Wisconsin Golf Turf Symp. Milwaukee.

Holmes, J.L. 1980. Sand greens-sand top-dressing. Proc. Fifteenth Annu. Wisconsin Golf Turf Symp. Milwaukee.

Jones, M. B., J.E. Street, and W.A. Williams 1974. Leaching and uptake of N applied to annual grass and clover-grass mixtues in lysimeters. Agron. J. 66:256-258.

Mancino, C.F. 1983. Studies of the fate of NO and $\mathrm{NH}_{4}^{+}$nitrogen from various fertilizers on turfgrasses grown on three different soil types. MS thesis. Univ. of Massachusetts, Amherst.

Mitchell, W.H., A.L. Morehart, L.J. Cotnoir, B.B Hessekine, and D.N. Langston, III. 1978. Ef fect of soil mixtures and irrigation methods on leaching of $\mathrm{N}$ in golf greens. Agron. J. 70:2935.

Petrovic, A. M.. and N.W. Hummel. 1985. Nitrogen source effects on nitrate leaching from late fall nitrogen applied to turfgrass. Agron. Abstr. p. 120

Petrovic, A. M., N.W. Hummel, Jr., and M.J. Carroll. 1986. Nitrogen source effects on nitrate leaching from late fall nitrogen applied to turfgrass. Agron. Abstr. p. 137

Rieke, P.E. and D.E. Ellis. 1974. Effects of N fertilization on nitrate movements under turfgrass. Proc. 2nd IntL Turfgrass Res. Conf. Madison, Wis.

Smika, D. E., D.F. Heermann, H.R. Duke, and A.R. Bathchelder. 1977. Nitrate-nitrogen percolation through irrigated sandy soil as affected by water management. Agron. J. 69:623-626.

Starr, J.L. and H.C. DeRoo. 1981. The fate of nitrogen fertilizer applied to turf. Crop Sci. 21:531-536.

Volk, G.M. and C.E. Bell. 1945. Some major factors in the leaching of calcium, potassium, sulfur, and nitrogen from sandy soils. Fla. Agr. Expt. Sta. Bul. 416.

HortSCIENCE 25(2):196-198. 1990.

\title{
Vegetative Propagation of Mexican Redbud, Larchleaf Goldenweed, Littleleaf Ash, and Evergreen Sumac
}

\author{
Jimmy L. Tipton' \\ Texas A\&M Research and Extension Center, 1380 A\&M Circle, El Paso, \\ TX 79927
}

Additional index words. Cercis canadensis var. mexicana, Ericameria laricifolia,

Fraxinus greggii, Rhus virens, woody plants, IBA

Abstract. Effect of cutting age (weeks after budbreak) and K-IBA concentration on percent rooting of Mexican redbud [Cercis canadensis var. mexicana (Rose) M. Hopkins], larchleaf goldenweed [Ericameria laricifolia (Gray) Shinners], littleleaf ash (Fraxinus greggii Gray), and evergreen sumac (Rhus virens Gray) were investigated. For cuttings treated with K-IBA, maximum predicted percent rooting from regression analysis was $88 \%$ for cuttings of Mexican redbud taken 4 weeks after budbreak and treated with 21 g.liter ${ }^{-1}, 99 \%$ for larchleaf goldenweed taken 6 weeks after budbreak and treated with $16 \mathrm{~g} \cdot$ liter $^{-1}, 86 \%$, for littleleaf ash taken 16 weeks after budbreak and treated with 17 g-liter ${ }^{-1}$, and $24 \%$ for cuttings of evergreen sumac taken 16 weeks after budbreak and treated With $5 \mathrm{~g} \cdot \mathrm{liter}^{-1}$. Chemical names used: potassium salt of 1H-indole-3-butanoic acid (K-IBA).

Mexican redbud, larchleaf goldenweed, littleleaf ash, and evergreen sumac are southwestern shrubs with potential as adapted ornamental for the area (Duffield and Jones, 1981; Miller, 1978; Nokes, 1986). Germplasm collections of all four species exhibit variability in floral color (Mexican redbud) or growth habit (larchleaf goldenweed, littleleaf ash, evergreen sumac) that could be exploited through vegetative propagation to provide superior plants. I found no reports regarding rooting of stem cuttings of these species, but studies on related species indicate timing and IBA concentration are critical. Despite an early report that nontreated stem cuttings of eastern redbud (Cercis canadensis L.) taken in June and July rooted $75 \%$ to $90 \%$ in 4 weeks (Thomas, 1936), other authors report little success in rooting softwood or semi-hardwood cuttings (Dirr and Heuser, 1987; Hartmann and Kester, 1975; Nokes, 1986). Ashes (Fraxinus spp.) are considered very difficult to propagate from stem cuttings (Dirr and Heuser, 1987). One percent of softwood cuttings of fragrant ash (Fraxinus cuspidata Torrey) treated with an auxin-tale preparation of $0.8 \mathrm{~g} \mathrm{IBA} / \mathrm{g}$ rooted (B.J. Simpson, personal communication). Softwood and semi-hardwood cuttings of fragrant sumac (Rhus aromatica Ait.), a deciduous species, rooted after treatment with IBA at $1 \mathrm{~g} \cdot$ liter $^{-1}$ (Tracz, 1983). According

Received for publication 27 Dec. 1988. All programs and information of the Texas Agricultural Experiment Station are available without regard to race, ethnic origin, religion, sex, and age. The cost of publishing this paper was defrayed in part by the payment of page charges. Under postal regulations, this paper therefore must be hereby marked advertisement solely to indicate this fact.

'Present address: Dept. of Plant Science, Univ. of Arizona, Tucson, AZ 85721. to Nokes (1986), semi-hardwood cuttings of evergreen sumac treated with an auxin-tale preparation of IBA at $0.8 \mathrm{~g} \cdot \mathrm{g}^{-1}$ have rooted. It appears that no attempts to root cuttings of larchleaf goldenweed have been published.

This study was conducted to determine the effect of timing and K-IBA (potassium salt) concentration on the rooting of stem cuttings of the four species. To avoid ambiguity in softwood and semi-hardwood terminology, leafy terminal stem cuttings 10 to $15 \mathrm{~cm}$ long were taken from single cultivated plants 4 , 8,12 , and 16 weeks after budbreak for each plant. Test plants were selected based on desirable characteristics - a dark flower color for Mexican redbud and an apparent rapid growth rate for the remaining species. Except littleleaf ash, all plants were at least 7 years old, had bloomed for several years, and were in the adult growth phase. The littleleaf ash was also 7 years old, but had not bloomed. Cuttings from each collection date were wounded by pressing the basal $10 \mathrm{~mm}$ against a replacement blade for an electric razor, producing eight parallel cuts $\approx 1.2 \mathrm{~mm}$ apart perpendicular to the stem axis. Cuttings from each collection date were divided into six groups of 20 cuttings each and each group was dipped for $5 \mathrm{sec}$ in one of six solutions containing K-IBA at 0 to $25 \mathrm{~g} \cdot \operatorname{liter}^{-1}$ in deionized water, at $5 \mathrm{~g} \cdot$ liter $^{-1}$ increments.

Table 1. Analysis of variance for the effect of K-IBA concentration on percent rooting of cuttings of Mexican redbud taken 4 weeks after budbreak.

\begin{tabular}{lcc}
\hline \hline Source & df & Mean square \\
\hline Model & 3 & $2172.78^{* *}$ \\
Total error & 7 & 16.22 \\
Lack of fit & 2 & $37.45^{\text {Ns }}$ \\
Pure error & 5 & 7.32 \\
Ns,**Nonsignificant or significant at $P=0.01$, \\
respectively.
\end{tabular}

